\title{
Clinical and Laboratory Study of Children Exposed in utero to Maternal Rubella
}

\author{
CATHERINE S. PECKHAM \\ From The Hospital for Sick Children and The Institute of Child Health, London
}

\begin{abstract}
Peckham, C. S. (1972). Archives of Disease in Childhood, 47, 571. Clinical and laboratory study of children exposed in utero to maternal rubella. Clinical and serological findings are described in 218 children aged 1 to 4 years who were exposed in utero to maternal rubella infection, and who were apparently normal at birth. 84 children were reassessed at 6 to 8 years of age. At the first examination, $23 \%$ of children had rubella-like defects, the most common of which was deafness associated in some cases with retinopathy. There was a close correlation between the incidence of rubella defects and both the time of exposure to maternal rubella and the presence or absence of rubella antibodies in the blood at the first examination ( 1 to 4 years). Children who were seropositive and who were exposed to maternal rubella before the 20th week of pregnancy were at highest risk. Of the 84 children who were reassessed at 6 to 8 years of age, further defects were detected in 9 out of the 49 seropositive children. No further defects were encountered in the seronegative group. $17 \%$ of initially seropositive children showed loss of antibody by the second examination, but this, with one exception, was confined to normal children with low antibody titres. These findings stress the importance of long-term follow-up in children at greatest risk.
\end{abstract}

This study was undertaken to assess the clinical and serological status of a group of children who were exposed to maternal rubella infection, and who were apparently normal at birth.

The study arose from a prospective survey carried out by the Public Health Laboratory Service to determine the effectiveness of immunoglobulin in the prevention of fetal damage after contact with rubella in early pregnancy (McDonald, 1963; McDonald and Peckham, 1967).

Since some rubella defects may not be apparent at birth (Sheridan, 1964; Manson, Logan, and Loy, 1960), a longitudinal follow-up is necessary in order to evaluate their true incidence. In the majority of children with multiple rubella defects, and in particular those with congenital heart defects, the defect manifests itself in the first year of life, but when deafness is the sole defect, even when severe, it may not be detected until after the first year, or when speech fails to develop normally (Jackson and Fisch, 1958; Barr and Lundström, 1961).

A preliminary report on the 2-year examination of some of the children in the study has been published previously (Butler et al., 1965).

Received 13 December 1971.

\section{Materials and Methods}

Group studied. In the prospective study carried out by the Public Health Laboratory Service some 30,000 women were given immunoglobulin between 1956 and 1962, after contact with rubella in pregnancy. A proportion of these women developed clinical rubella despite administration of immunoglobulin. In addition, a small group were given immunoglobulin after the appearance of the rash, in the hope of modifying the disease (McDonald and Peckham, 1967). The diagnosis of rubella was made on clinical grounds as no laboratory diagnosis was available, but as most cases occurred during the 1962 rubella epidemic, the reliability of the diagnosis seems reasonably certain (Fig. 1).

As the incidence of rubella-type defects in this group was lower than expected (McDonald and Peckham, 1967), it was decided to examine as many children as possible who had been exposed to maternal rubella but who were normal at birth.

First follow-up examination. The first follow-up examination was carried out on 237 children (126 boys, 111 girls) between the ages of 1 and 4 years; 108 of these children were seen at The Hospital for Sick Children, Great Ormond Street, and the remainder at various centres throughout the country; $93 \%$ of these children were seen personally. $190(80 \%)$ of the children were 2 years of age. This is a convenient age to assess the 


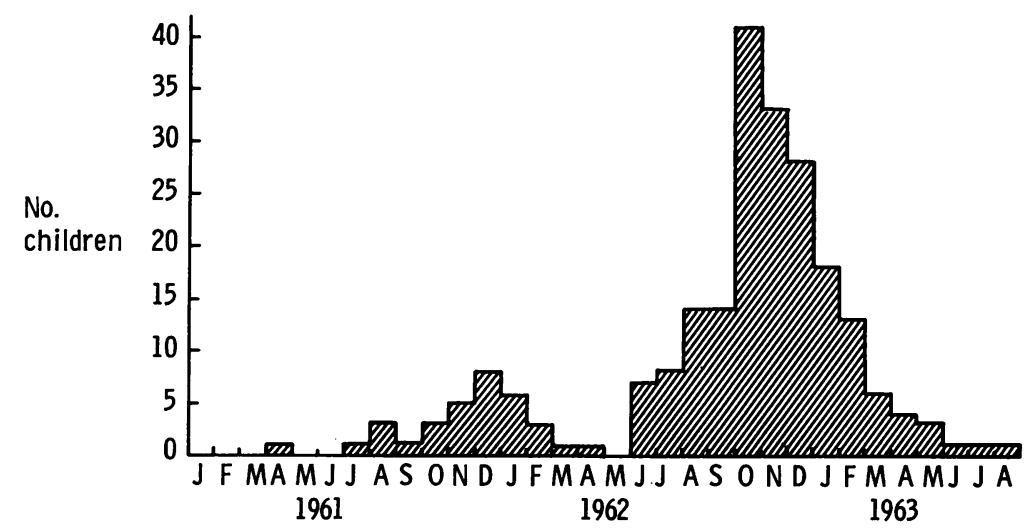

FIG. 1.-Month of birth of study children born in 1961-63.

children because deafness should be detectable clinically and the presence of rubella antibody enables a retrospective diagnosis of intrauterine infection to be made with some degree of confidence, as maternally transmitted antibody has by this time disappeared. The presence of antibody acquired from natural exposure is uncommon before the age of 4 years.

The time sequence of immunoglobulin administration to the mothers of these children in relation to rubella rash was as follows. 182 mothers developed rash after immunoglobulin: 34 between 0 and 8 days, 71 between 9 and 17 days, 42 between 18 and 26 days, 33 in 27 or more days, and in 2 the number of days after the administration of immunoglobulin was not known.

In addition, 55 mothers had received immunoglobulin after the onset of the rash.

The examination was similar to that described in the preliminary report (Butler et al., 1965). A detailed history was taken and a complete physical examination was made, including an auditory and ophthalmic assessment. The Stycar test devised by Sheridan (1958) was used for the detection of hearing defects. This was carried out at one visit to the hospital centre arranged for this purpose. Any child found to have a defect was referred to the appropriate department for further assessment and advice.

Second follow-up examination. 85 of the 108 children who were initially examined at The Hospital for Sick Children were personally re-examined at 6 to 8 years of age. Again a complete physical examination was made, and tests for speech, vision, hearing, and motor co-ordination were carried out. In addition, a full pure-tone audiogram was taken.

Serological studies. At the first examination blood was taken from 218 of the 237 children and tested for rubella neutralizing antibody to enable a retrospective diagnosis of intrauterine rubella to be made. Sera were tested in RK13 cells by the method previously described from this laboratory (Dudgeon, Butler, and
Plotkin, 1964). Antibody titres of 4 or greater were regarded as positive and those with titres of less than 4 as negative. In 3 cases where neutralizing antibody could not be measured due to contamination of sera, the sample was later tested for rubella antibody by the haemagglutination-inhibition (HI) test.

At the second examination at 6 to 8 years of age carried out on 85 children, a further blood sample was taken and tested for rubella antibody. The micromethod described by Steward et al. (1967) was used with a few modifications in use in this laboratory, notably the removal of nonspecific inhibitors of haemagglutination by treatment with a mixture of heparin and manganous chloride (Marshall et al., 1971).

\section{Results}

First follow-up. Serological data were available in 218 out of 237 children examined at 1 to 4 years of age. In the remaining 19 children no serological results were obtained, due mainly to contamination of specimens, so they have been excluded from this study. Table I shows the number of children with rubella antibody (seropositive) and without detectable antibody (seronegative). 118

TABLE I

Children With and Without Rubella Antibody at 1 to 4 Years of Age

\begin{tabular}{l|c|c|c}
\hline $\begin{array}{c}\text { Time of } \\
\text { Administration of } \\
\text { Immunoglobulin }\end{array}$ & Seropositive & Seronegative & Total \\
\cline { 2 - 4 } & Serological Status & \\
\hline $\begin{array}{c}\text { Before onset of } \\
\text { rash }\end{array}$ & $86(52 \cdot 1 \%)$ & $79(47 \cdot 9 \%)$ & $165(100 \%)$ \\
$\begin{array}{l}\text { After onset of } \\
\text { rash }\end{array}$ & $32(60 \cdot 4 \%)$ & $21(39 \cdot 6 \%)$ & $53(100 \%)$ \\
\hline Total & $118(54 \cdot 1 \%)$ & $100(45 \cdot 9 \%)$ & $218(100 \%)$ \\
\hline
\end{tabular}


TABLE II

Rubella Defects in Relation to Serological Status and Week of Maternal Rash (Children aged 1 to 4 Years)

\begin{tabular}{|c|c|c|c|c|c|c|c|c|c|}
\hline \multirow{2}{*}{ Immune Status of Child } & \multicolumn{8}{|c|}{ Week of Maternal Rash } & \multirow{2}{*}{ Total } \\
\hline & $0-4$ & $5-8$ & $9-12$ & $13-16$ & $17-20$ & $21-24$ & $25-28$ & +28 & \\
\hline $\begin{array}{l}\text { Seropositive } \\
\text { Without rubella defect } \\
\text { With rubella defect }\end{array}$ & $\begin{array}{l}2 \\
1\end{array}$ & $\begin{array}{r}2 \\
11\end{array}$ & $\begin{array}{l}21 \\
23\end{array}$ & $\begin{array}{r}31 \\
7\end{array}$ & $\begin{array}{r}15 \\
3\end{array}$ & $\frac{2}{-}$ & $\bar{z}$ & $\overline{-}$ & $\begin{array}{l}73(61 \cdot 8 \%) \\
45(38 \cdot 2 \%)\end{array}$ \\
\hline Total & 3 & 13 & 44 & 38 & 18 & 2 & - & 一 & $118(100 \%)$ \\
\hline $\begin{array}{l}\text { Seronegative } \\
\text { Without rubella defect } \\
\text { W'ith rubella defect }\end{array}$ & $\overline{-}$ & $\begin{array}{l}9 \\
2\end{array}$ & $\begin{array}{r}22 \\
1\end{array}$ & $\frac{35}{-}$ & $\begin{array}{r}21 \\
1\end{array}$ & $\begin{array}{l}4 \\
1\end{array}$ & $\frac{3}{-}$ & 1 & $\begin{array}{c}95(95 \%) \\
5(5 \%)\end{array}$ \\
\hline Total & 一 & 11 & 23 & 35 & 22 & 5 & 3 & 1 & $100(100 \%)$ \\
\hline Grand total & 3 & 24 & 67 & 73 & 40 & 7 & 3 & 1 & 218 \\
\hline
\end{tabular}

of the 218 children (54\%) possessed antibody irrespective of whether their mothers had received immunoglobulin before or after the appearance of the rubella rash; $100(46 \%)$ were seronegative.

Children whose mothers had received immunoglobulin either before or after the rash are considered together, as a separate analysis showed that the outcome in terms of defects was similar in both groups.

Table II shows the incidence of rubella defects in relation to serological status and week of maternal infection. 168 of the 218 children examined showed no abnormality of the rubella type, but 50 children were found to have one or more defects compatible with congenital rubella. 45 of these 50 children with rubella-type defects were seropositive, their antibody titres varying from 8 to 256. Only $5(5 \%)$ out of 100 seronegative children had defects.

Details of the types of defects encountered are summarized in Table III. Deafness, either alone or in combination, was the most common abnormality accounting for 35 out of the 50 rubella-type defects. Deafness was bilateral in all cases, it was usually severe, and in 13 children was accompanied by pigmentary retinopathy. In 2 deaf children there was coexistent persistent ductus. One child had glaucoma and cerebral palsy. No cases of

TABLE III

Rubella-type Defects According to Antibody Status and Week of Maternal Rash (Age 1 to 4 Years)

\begin{tabular}{|c|c|c|c|c|c|c|c|}
\hline & \multicolumn{6}{|c|}{ W'eek of Maternal Rash } & \multirow{2}{*}{ Total } \\
\hline & $0-4$ & $5-8$ & $9-12$ & $13-16$ & $17-20$ & $21-24$ & \\
\hline $\begin{array}{l}\text { Seropositive } \\
\text { Deaf with retinopathy } \\
\text { Deaf with heart defect } \\
\text { Deaf a'one } \\
\text { Retinopathy alone } \\
\text { Glaucoma and cerebral palsy }\end{array}$ & $\begin{array}{l}\overline{1} \\
\overline{-}\end{array}$ & $\begin{array}{l}2 \\
2^{\star} \\
3 \\
3 \\
1\end{array}$ & $\begin{array}{r}11 \\
7 \\
5 \\
-\end{array}$ & $\begin{array}{l}- \\
-6 \\
1 \\
-\end{array}$ & $\begin{array}{l}\text { Z } \\
1 \\
2 \\
-\end{array}$ & $\begin{array}{l}\bar{Z} \\
\bar{z}\end{array}$ & $\begin{array}{r}13 \\
2 \\
18 \\
11 \\
1\end{array}$ \\
\hline $\begin{array}{l}\text { Total } \\
\text { Seronegative } \\
\text { Deaf with retinopathy } \\
\text { Deaf with heart defect } \\
\text { Deaf alone } \\
\text { Retinopathy alone }\end{array}$ & $\begin{array}{l}1 \\
= \\
=\end{array}$ & $\begin{array}{l}11 \\
\frac{-}{1} \\
1\end{array}$ & $\begin{array}{l}23 \\
\frac{-}{1}\end{array}$ & $\begin{array}{l}7 \\
= \\
=\end{array}$ & $\begin{array}{l}3 \\
\bar{Z} \\
\frac{1}{1}\end{array}$ & $\begin{array}{l}- \\
\overline{1} \\
-\end{array}$ & $\begin{array}{r}45 \\
- \\
- \\
3\end{array}$ \\
\hline Total & 一 & 2 & 1 & - & 1 & 1 & 5 \\
\hline
\end{tabular}

$\star_{1}$ case associated with retinopathy. 
cataract were observed. Pigmentary retinopathy of the rubella type was the sole abnormality in 14 children.

Five of the seronegative children had rubellatype defects; 2 had bilateral deafness and 3 had pigmentary retinopathy as the sole defect.

In the seropositive group of children there was a higher incidence of defects when rubella occurred early in pregnancy. The frequency of defects in relation to time of fetal exposure is set out in Table IV.

TABLE IV

Incidence of Defects

\begin{tabular}{c|c|c|c|c}
\hline \multirow{2}{*}{$\begin{array}{c}\text { Week } \\
\text { of } \begin{array}{c}\text { Maternal } \\
\text { Rash }\end{array}\end{array}$} & \multicolumn{2}{|c|}{ Seropositive Children } & \multicolumn{2}{|c}{ All Children } \\
\cline { 2 - 4 } & No. & $\%$ & No. & $\%$ \\
\hline $0-8$ & $12 / 16$ & $75 \cdot 0$ & $14 / 27$ & $51 \cdot 8$ \\
$9-12$ & $23 / 44$ & $52 \cdot 3$ & $24 / 67$ & $35 \cdot 8$ \\
$13-16$ & $7 / 38$ & $18 \cdot 4$ & $7 / 73$ & $9 \cdot 6$ \\
$17-20$ & $3 / 18$ & $16 \cdot 7$ & $4 / 40$ & $10 \cdot 0$ \\
+20 & $0 / 2$ & - & $1 / 11$ & $10 \cdot 0$ \\
& & & & \\
\hline
\end{tabular}

In 7 other children congenital anomalies were present which were not considered to be rubellatype defects. These included bilateral hernia, Marcus Gunn syndrome, pyloric stenosis (2 cases), bilateral talipes, syndactyly of fingers, and hand deformity. 4 occurred in the seropositive group and 3 in the seronegative group.

Birthweight and rubella defect. The birthweight of seropositive children in relation to gestational age (4 children were excluded as the gestational age was unknown) showed that 13 of the 33 children $(39 \cdot 4 \%$ ) with rubella-type defects (excluding retinopathy) had birthweights below the 10th centile, whereas only 10 of the 81 normal children $(12 \cdot 3 \%)$ were below this line (centiles from the Perinatal Mortality Data of Butler and Alberman, 1969). The birthweights of 11 children in whom retinopathy was the sole defect were above the 10th centile.

Second follow-up. 85 children were reexamined at 6 to 8 years of age (Table V). 49 were initially seropositive and 36 seronegative at 2 years of age. $8(16.3 \%)$ of the children who had low antibody levels at 2 years of age were seronegative at 6 to 8 years, and $13(36 \cdot 1 \%)$ of the previously seronegative children had acquired antibody, presumably from natural infection. Reassessment of the 85 children at this age revealed 9 further defects which had not been detected at the previous examination. These all occurred in children who had been initially seropositive and included 3 children with bilateral deafness, 4 with unilateral deafness, and 2 with retinopathy associated in one child with retarded development.

Seven of the nine new defects were in children previously found to be normal (Table VI). Of the 5 children whose sole initial defect had been retinopathy, 2 were found to be deaf at the second examination. 16 initially deaf children and 1 child with glaucoma and cerebral palsy were also reassessed. Hence by 6 to 8 years of age, 29 out of the $49(59 \%)$ initially seropositive children had clinical manifestations of congenital rubella (Table VII). The incidence of defects was again related to the time of maternal rubella infection. Of the 29 seropositive children exposed in utero in the first 12 weeks of pregnancy, $82 \%$ showed evidence of congenital rubella abnormalities at 6 to 8 years of age. All but 3 children with bilateral hearing loss were severely handicapped and attending partial hearing units or special schools for the deaf. In spite of this the deaf children had adapted well to their handicaps and obtained a reasonable level of performance; there was no indication of mental retardation. One child with classic autism was thought to have a bilateral moderate hearing loss, though assessment was difficult. It is of

TABLE V

Antibody Status of 85 Children Born to Mothers with Rubella in Pregnancy (Examined at 1 to 4 Years and 6 to 8 Years)

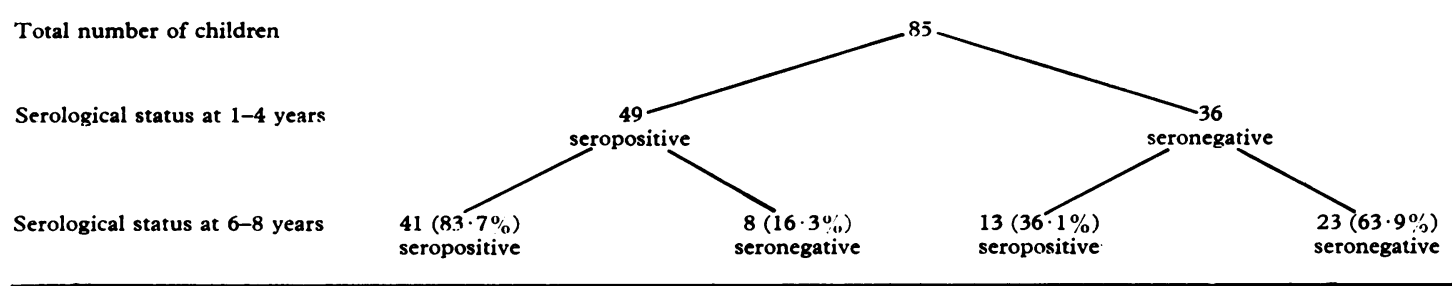


TABLE VI

Clinical and Serological Status of Children Born After Maternal Rubella in Pregnancy

\begin{tabular}{c|c|c}
\hline $\begin{array}{c}\text { Age at Examination } \\
(\mathrm{yr})\end{array}$ & $\begin{array}{c}\text { No. with Defects } \\
\text { No. Seropositive }\end{array}$ & $\begin{array}{c}\text { No. with Defects/ } \\
\text { No. Seronegative }\end{array}$ \\
\hline $1-4$ & $22 / 49$ & $0 / 36$ \\
$6-8$ & $29 / 49$ & $0 / 36$ \\
\hline
\end{tabular}

interest that at the first examination (18 months) of this child, deafness was detected but it was noted that the child's behavioural pattern was abnormal. There was no other case of mental retardation apart from the child with retinopathy mentioned previously. Retinopathy was not associated in any instance with visual impairment. No rubella defects were detected in the remaining 36 children who were initially seronegative.

In 36 of the children who were examined at 6 to 8 years of age, enough serum was available from the first examination to allow simultaneous testing of paired serum collected at first and second follow-up, for the presence of rubella $\mathrm{HI}$ antibody (Fig. 2). 26 children showed no significant change in antibody level, in 5 children there was a fourfold decline, and in 5 complete loss of antibody. In the latter group the previous levels of $\mathrm{HI}$ antibody were low and only one child had a defect-unilateral deafness.

\section{Discussion}

It is apparent from the results that children exposed in utero to maternal rubella and who possess rubella antibody, but are apparently normal at birth, should be assessed at intervals, since deafness may become apparent in a proportion of these children, and if unrecognized would adversely affect their development. In addition, since late detection of hearing loss may affect a child emotionally it is important that the handicap is picked up early so that the child can be given as much help as possible, including fitting of hearing aids, speech therapy, auditory training, and lip reading. This is particularly relevant to congenital perceptive rubella deafness which is rarely complete, but which may deteriorate so that the sooner the hearing loss is established the greater the chance the child has of adapting to his handicap. Deafness may be very difficult to detect in the young child, and though it is appreciated that auditory testing at 2 years is not directly comparable with detailed audiometry at 7 , in many cases there

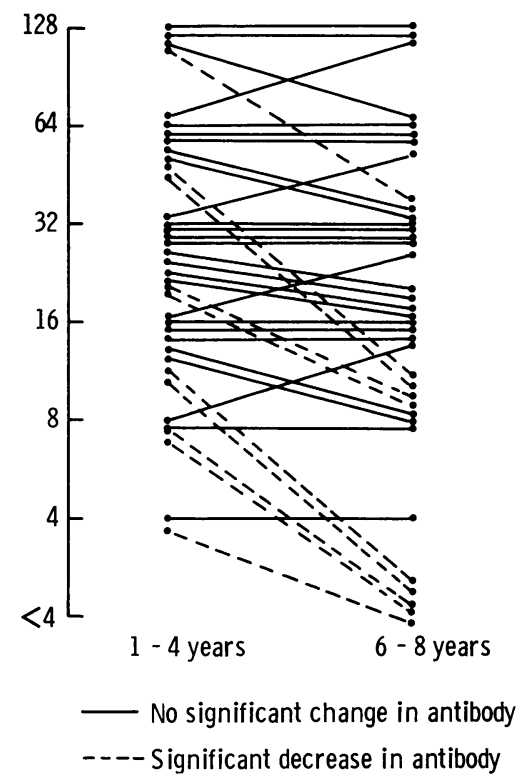

FIG. 2.-Rubella HI antibody titre in paired sera (36 children).

TABLE VII

Defects in 49 Children who were Seropositive at 1 to 4 Years and Re-examined at 6 to 8 Years

\begin{tabular}{|c|c|c|c|c|c|}
\hline & \multicolumn{4}{|c|}{ Week of Maternal Rubella } & \multirow{2}{*}{ Tota } \\
\hline & $0-8$ & $9-12$ & $13-16$ & $17-20$ & \\
\hline $\begin{array}{l}\text { Number of children examined } \\
\text { Total with no defects } \\
\text { Bilateral deafness and retinopathy } \\
\text { Bilateral deafness } \\
\text { Unilateral deafness and retinopathy } \\
\text { Unilateral deafness } \\
\text { Retinopathy alone } \\
\text { Glaucoma and cerebral palsy } \\
\text { Total with defects }\end{array}$ & $\begin{array}{c}10 \\
1 \\
2 \\
4^{\star} \\
1 \\
1 \\
1 \\
9\end{array}$ & $\begin{array}{r}19 \\
5 \\
-1 \\
2 \\
\frac{3}{14}\end{array}$ & $\begin{array}{r}13 \\
7 \\
3 \\
1 \\
1 \\
-1 \\
6\end{array}$ & $\begin{array}{l}7 \\
- \\
- \\
- \\
-\end{array}$ & $\begin{array}{r}49 \\
20 \\
14 \\
5 \\
2 \\
2 \\
5 \\
1 \\
29\end{array}$ \\
\hline
\end{tabular}

^ 1 case with persistent ductus; 1 case autistic. 
appears little doubt that an actual deterioration of hearing had occurred. On the other hand, defective hearing may be of central origin (Ames et al., 1970). As affected children are known to excrete the virus beyond the newborn period, rubella virus may well persist in the middle ear and continue to inflict damage beyond the newborn period. The reported isolation of rubella virus from the cataractous tissue several years after birth (Reid and Murphy, 1966) adds some support to this suggestion.

In the present series, 15 children aged from 6 to 8 years with bilateral deafness who were attending special schools (6), or partial hearing units (9), appeared to have shown satisfactory adaptation to their disability and there was no evidence of severe intellectual impairment. One child had won a painting competition at the handicapped children's art exhibition. However, 2 of the 3 bilaterally deaf children attending normal schools had adapted poorly and their progress in class was retarded despite the provision of hearing aids and speech therapy. These 2 children were not mentally retarded but were unable to cope with the normal school situation. The partially deaf autistic child was attending a training centre while awaiting more suitable placement.

The earlier in pregnancy that the fetus is exposed to maternal rubella the greater the chance of a malformed child. In this series no defects occurred after 20 weeks in the seropositive group of children. There was one case of retinopathy in a seronegative child exposed at 20 weeks. There is a close correlation between the presence of rubella antibody in the child and the presence of defects. Of the 50 children with rubella defects, $90 \%$ were seropositive. It is also apparent that new defects were only identified at the 6 to 8-year follow-up in children who were previously seropositive. Since nearly $50 \%$ of seropositive children exposed to maternal rubella in the first 4 months of pregnancy were found to be deaf at 6 to 8 -year examination, it is important to determine the serological status of children exposed in utero to maternal infection. This should be done as soon as possible after 6 months of age when maternal antibodies have disappeared. The presence of rubella antibody occurring as a result of natural infection is unlikely before the age of 4 ; in a random series of 140 children aged between 1 and 4 years seen in Medical Out-patients at The Hospital for Sick Children, only $5 \%$ had rubella antibody, compared to $53.9 \%$ of the present series (W. C. Marshall, personal communication, 1971).

There appears to be no particular advantage in the intensive long-term follow-up of seronegative children adequately assessed to be normal when the $\overrightarrow{\vec{F}}$ initial blood sample was taken after 6 months of $\stackrel{\mathcal{O}}{\rightarrow}$ age. It is clear that these children have not lost $\bar{c}$ their ability to develop natural rubella infection; 을 approximately $35 \%$ had become seropositive by $\frac{\bar{\omega}}{\overrightarrow{0}}$ 7 years of age. This is the proportion that would $\stackrel{\mathbb{Q}}{\Omega}$ be anticipated in a normal population.

Rubella antibody was lost by the age of 7 in a

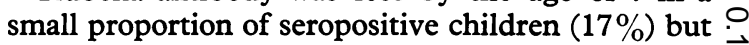
only one child with a rubella defect lost antibody. $\vec{\omega}$ In addition, loss of antibody was confined to children with initially low antibody titres (16 or less), 气̊ำ whereas the majority of children with defects had titres of more than 32. The duration of antibody response has generally been considered to last for $\mathrm{N}$ many years (Dudgeon, Marshall, and Soothill, $\overrightarrow{i r}$ 1969), but Hardy and her colleagues reported that some patients lose antibody by 2 to 3 years of age 음 (Hardy, Sever, and Gilkeson, 1969).

Pigmentary retinopathy is not in itself a $\vec{\nabla}$ serious defect but is associated with more serious defects. 2 of the 5 children who had $\underset{c}{\stackrel{c}{a}}$ retinopathy as the sole defect at first follow-up and who were examined at 7 years of age were found to be deaf. Examination of the fundus is difficult in an active 2-year-old and retinopathy may be missed, so that not too much reliance should be placed on its absence.

Low birthweight for gestational age is considered to be one of the stigmata of congenital rubella. The results of this study indicate, however, that low birthweight is associated with other rubella-like defects, but is uncommon as the sole manifestation of rubella. $33 \%$ of the children with defects were below the 10th centile for weight, whereas only $12 \%$ of normal seropositive children were below this limit. In a study on children with severe multiple rubella defects, $51 \%$ had birthweights falling below the 10th centile (Gumpel, 1972). There is thus no evidence that retarded fetal growth occurs as a sole manifestation of congenital rubella.

Though in this series the incidence of rubella defects is high, most of the defects were single defects. The absence of cataracts, heart defects, and severe multiple defects characteristic of congenital rubella was remarkable. This may be relevant to the management of the pregnant woman in contact with rubella who elects to go to term, and where immunoglobulin can be given.

This study has been made possible by the co-operation of paediatricians in numerous centres throughout the country, and I am indebted to them for their help. I am grateful to Dr. J. A. Dudgeon, Director, Department of Microbiology, Institute of Child Health and 
The Hospital for Sick Children, for his advice and encouragement, and to Mr. G. Hawkins for technical assistance.

This work was begun at the Central Public Health Laboratory, Colindale, while the author was in receipt of a Medical Research Council grant.

\section{REFERENCES}

Ames, M. D., Plotkin, S. A., Winchester, R. A., and Atkins, T. E. (1970). Central auditory imperception: a significant factor in congenital rubella deafness. Fournal of the American Medical Association, 213, 419.

Barr, B., and Lundström, R. (1961). Deafness following maternal rubella: retrospective and prospective studies. Acta Otolaryngologica, 53, 413.

Butler, N. R., and Alberman, E. D. (Editors) (1969). Perinatal Problems: The Second Report of the 1958 British Perinatal Mortality Survey. (National Birthday Trust Fund.) Livingstone, Edinburgh.

Butler, N. R., Dudgeon, J. A., Hayes, K., Peckham, C. S., and Wybar, K. (1965). Persistence of rubella antibody with and without embryopathy. British Medical fournal. 2, 1027.

Dudgeon, J. A., Butler, N. R., and Plotkin, S. A. (1964). Further serological studies on the rubella syndrome. British Medical fournal, 2, 155.

Dudgeon, J. A., Marshall, W. C., and Soothill, J. F. (1969). Immunological responses to early and late intrauterine virus infections. fournal of Pediatrics, 75, 1149.

Gumpel, S. M. (1972). Clinical and social status of patients with congenital rubella. Archives of Disease in Childhood, 47, 330.

Hardy, J. B., Sever, J. L., and Gilkeson, M. R. (1969). Declining antibody titers in children with congenital rubella. Fournal of Pediatrics, 75, 213.
Jackson, A. D. M., and Fisch, L. (1958). Deafness following maternal rubella: results of a prospective investigation. Lancet, $2,1241$.

McDonald, J. C. (1963). Gamma-globulin for prevention of rubella in pregnancy. British Medical fournal, 2, 416.

McDonald, J. C., and Peckham, C. S. (1967). Gammaglobulin in prevention of rubella and congenital defect: a study of 30,000 pregnancies. British Medical fournal, 3, 633.

Manson, M. M., Logan, W. P. D., and Loy, R. M. (1960). Rubella and other virus infections during pregnancy. Reports on Public Health and Medical Subjects (Ministry of Health), 101.

Marshall, W. C., Peckham, C. S., Darby, C. P., Dudgeon, J. A. and Hawkins, G. T. (1971). Further studies with rubella vaccines in adults and children. Practitioner, 207, 632.

Reid, R. R., and Murphy, A. M. (1966). Isolation of rubella virus from congenital cataracts removed at operation. Medical Fournal of Australia, 1, 540.

Sheridan, M. D. (1958). Manual for the Stycar Hearing Test. National Foundation for Educational Research in England and Wales, London.

Sheridan, M. D. (1964). Final report of a prospective study of children whose mothers had rubella in early pregnancy. British Medical fournal, 2, 536.

Steward, G. L., Parkman, P. D., Hopps, H. E., Douglas, R. D. Hamilton, J. P., and Meyer, H. M., Jr. (1967). Rubella-virus hemagglutination-inhibition test. New England fournal of Medicine, 267, 554.

Correspondence to Dr. C. S. Peckham, The Hospital for Sick Children, Great Ormond Street, London WC1. 